\title{
PELATIHAN MEDIA PEMBELAJARAN INTERAKTIF BERBASIS MULTIMEDIA BAGI GURU-GURU SMAN 02 TANJUNGBALAI
}

\author{
Arridha Zikra Syah ${ }^{1 *}$, Rizaldi ${ }^{1}$, Yessica Siagian ${ }^{1}$, Norenta Sitohang ${ }^{1}$, \\ Ahmad Muhazir ${ }^{1}$ \\ ${ }^{\mathbf{1}}$ Program Studi Sistem Informasi, STMIK Royal Kisaran \\ Email : arridhazikrasyah@royal.ac.id
}

\begin{abstract}
Community service activities in the form of training of multimedia-based interactive learning media for teachers of SMAN 02 Tanjung BALAI aims to provide knowledge, skills, which are expected to result in changes in knowledge, skills and attitudes of teachers. So that learning and teaching process can run smoothly and easy. The target audience in community service activities are SMA N 02 TanjungBalai. Activity of multimedia-based interactive learning media is presented with the method of preaching, demonstration and question and answer. The availability of adequate lecturers, the enthusiasm of participants, and the support of headmaster is a supporter of the terrestrial activity of the PKM. The obstacles faced is the ability of participants to use the application is still low and computer resources owned by some participants do not meet the multimedia processing specifications should be. Benefits derived from this activity, among others, participants can know about the importance of interactive multimedia media and abractive media to improve motivation and achievement of students who are educated participants. With the creation of learning media, the learning process will be more interesting, the students will be more motivated and passionate in learning, so that teachers can explain the subject matter more easily and attractively.
\end{abstract}

Keyword: Multimedia, Instructional Media, Interactive learning

\begin{abstract}
Abstrak: Kegiatan pengabdian kepada masyarakat berupa pelatihan pembuatan media pembelajaran interaktif berbasis multimedia bagi guru-guru SMAN 02 Tanjung Balai ini bertujuan untuk memberikan pengetahuan, keterampilan, yang diharapkan dapat menghasilkan perubahan pengetahuan, keterampilan dan sikap dari guru sehingga proses belajar dan mengajar dapat berjalan dengna lancar dan mudah. Khalayak sasaran dalam kegiatan pengabdian kepada masyarakat ini adalah guru-guru SMA N 02 TanjungBalai. Kegiatan pembuatan media pembelajaran interaktif berbasis multimedia ini disajikan dengan metodeceramah, demonstrasi dan tanya jawab. Ketersediaan dosen yang memadai, antusiasme peserta, dan dukungan kepala sekolah merupakan pendukung teralksananya kegiatan PKM ini.Adapun kendala yang dihadapi adalah kemampuan peserta menggunakan porgram aplikasi masih rendah serta sumberdaya komputer yang dimiliki sebagian peserta tidak memenuhi spefikasi pengolahan multimedia yang seharusnya. Manfaat yang diperoleh dari kegiatan ini antara lain peserta dapat mengetahui tentang arti pentingnya media pembelajaran multimedia yang interaktif dan abraktif untuk meningkatkan motivasi dan prestasi siswa yang dididik peserta. Dengan terciptanya media pembelajaran maka proses belajar mengajar akan lebih menarik, siswa akan lebih termotivasi dan bergairah dalam belajar, sehingga guru dapat menjelaskan materi pelajaran lebih mudah dan atraktif.
\end{abstract}

Kata Kunci: Multimedia, Media Pembelajaran, Pembelajaran interaktif 


\section{PENDAHULUAN}

Salah satu perkembangan pesat dari teknologi informasi adalah media pembelajaran, dimana dunia pendidikan sekarang ini sudah banyak menggunakan multimedia sebagai basis media pembelajaran interaktif.Peningkatan mutu pendidikan merupakan salah satu unsur konkrit yang sangat penting dalam upaya peningkatan kualitas sumber daya manusia.Sejalan dengan itu, hal yang sangat penting untuk diperhatikan adalah masalah prestasi belajar. Masalah umum yang sering dihadapi oleh peserta didik khususnya siswa masih cukup banyak yang belum dapat mencapai prestasi belajar yang memuaskan. Sebenarnya banyak faktor yang menyebabkan prestasi belajar tersebut mengalami kegagalan dalam bidang akademik baik faktor-faktor yang berada dalam diri siswa maupun faktor-faktor yang berada diluar diri siswa seperti tingkat intelegensi yang rendah, kurangnya motivasi belajar, cara belajar yang kurang efektif, minimnya frekuensi dan jumlah waktu belajar, tingkat disiplin diri yang rendah, media belajar atau bahan ajar yang masih kurang disediakan pihak sekolah dan sebagainya.Demi mencapai prestasi belajar yang memuaskan tersebut dengan system pendidikan yang semakin maju dan didukung juga dengan perkembangan teknologi. Teknologi multimedia telah menjanjikan potensi besar dalam merubah cara seseorang untuk belajar, untuk memperoleh informasi, menyesuaikan informasi dan sebagainya.

Pembelajaran berbasis multimedia menjadi semakin umum.Multimedia juga menyediakan peluang bagi pendidik untuk mengembangkan teknik pembelajaran sehingga menghasilkan hasil yang maksimal. Demikian juga bagi peserta didik, dengan multimedia diharapkan mereka akan lebih mudah untuk menentukan dengan apa dan bagaiamana siswa dapat menyerap informasi secara cepat dan efisien. Sumber informasi tidak lagi terfokus pada teks dari buku semata-mata tetapi lebih luas dari itu. Kemampuan teknologi multimedia yang semakin baik dan berkembang akan menambah kemudahan dalam mendapatkan pengetahuan siswa

Meskipun diketahui banyak manfaat dan kemudahan dalam penggunaan multimedia sebagai media pembelajaran, namun masih sedikit yang bisa menggunakan media tersebut. Berdasarkan observasi yang dilakukan dilapangan, pada SMAN 02 Tanjungbalai penyampaian materi pembelajaran selama ini bersifat konvensional yaitu menggunakan metode ceramah, guru-gurunya belum mencoba membuat dan menggunakan multimedia sebagai media pembelajaran interaktif guru, sehingga proses belajar kurang menarik dan cenderung membosankan.

Dari pemaparan di atas, Tim dosen STMIK Royal kisaran tertarik melakukan pengabdian masyarakat pada SMAN 02 Tanjungbalai untuk memberikan pelatihan. Adapun 
http://jurnal.stmikroyal.ac.id/index.php/jurdimas

software yang digunakan untuk membuat media pembelajaran interaktif adalah Microsoft Power Point 2010. Dengan didukung oleh software tersebut, diharapkan akan memberikan wawasan baru bagi guru dalam pembuatan media pembelajaran. Hasil dari kegiatan program pengabdian ini adalah guru menjadi lebih terampil dalam pembuatan media pembelajaran interaktif sehingga minat siswa terhadap pelajaran dapat lebih ditingkatkan dan pada akhirnya akan meningkatkan kualitas pembelajaran secara keseluruhan.

Setelah memperoleh kegiatan pelatihan ini,para peserta dapat mengetahui tentang arti pentingnya media pembelajaran multimedia yang interaktif dan atraktif untuk meningkatkan motivasi dan prestasi belajar siswa. Dengan terciptanya media pembelajaran yang dapat dimanfaatkan untuk semua mata pelajaran maka proses belajar mengajarakan lebih menarik,siswa akan lebih termotivasi dan bergairah belajar,sedangkan guru dapat menjelaskan materi pelajaran dengan lebih mudah dan atraktif.

Kegiatan pelatihan ini melibatkan guru - guru semua mata pelajaran yang ada di SMAN 02 Tanjung Balai.Alasan dipilihnya guru-guru pada jenjang SMA sebagai objek pelatihan karena dijenjang ini,diperlukan metode penyampaian pelajaran yang lebih atraktif dan interaktif,yang belum diperhatikan dengan baik.

\section{METODE}

Ada beberapa materi dan metode yang digunakan dalam pengabdian masyarakat ini, yaitu:

\section{Materi Pengabdian Kepada Masyarakat}

Pelatihan Pembuatan Media

Pembelajaran Interaktif menggunakan Power Point 2010 (Menu, Materi, Quis dan konversi ke video).

\section{Metode pengajaran yang dilakukan}

Metode pengajaran yang dilakukan adalah sebagai berikut :

1. Metode Transfer ilmu

Metode ini dilakukan dengan cara menularkan ilmu sekaligus memberikan pelatihan mengenai pembuatan media pembelajaran yang interaktif dan menarik bagi guruguru di SMAN 02 Tanjung Balai.

2. Metode Penyampaian

Metode penyampaian yang dilaksanakan dalam program ini adalah pelatihan dan praktek langsung. Peserta mempraktekkan secara langsung cara membuat media pembelajaran menggunakan perangkat lunak Microsoft Power Point 2010 sehingga lebih mudah dipahami. Dengan demikian tujuan yang diharapkan dalam pelaksanaan program ini dapat dicapai. Kegiatan ini dilaksanakan pada tanggal 16 September 2017 bertempat di SMAN 02, Jl. Jendral Sudirman, Tanjungbalai Kabupaten Asahan Sumatera Utara.Susunan kegiatan dan jadwal kegiatan meliput tahap pengenalan multimedia, multimedia pembelajaran, pembuatan aplikasi multimedia interaktif mulai dari instalasi software utama dan pendukung sampai ke tahap per tahap pembuatan aplikasi, dilanjutkan dengan tanya jawab.Kegiatantanya jawab dilakukan bersamaan dengan penyajian materi.Para peserta dapat langsung berdiskusi dengan para 
pemateri secara langsung untuk lebih memahami materi dan sharing pengalaman terkait dengan masalah yang tengah dibahas dengan materi bersangkutan.

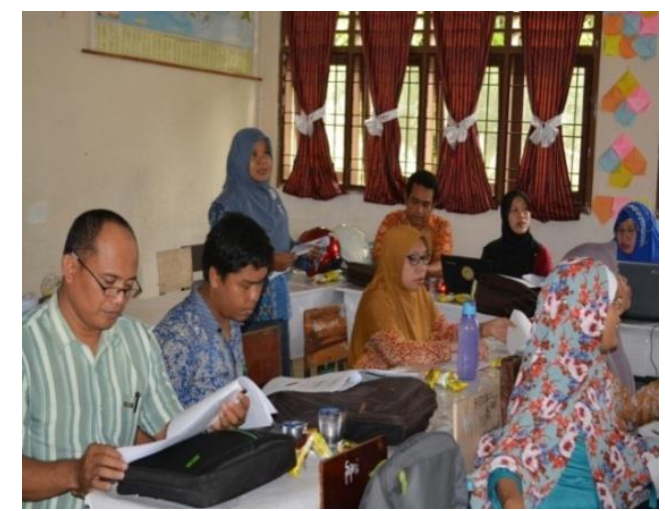

Gambar 1 Peserta Pengabdian

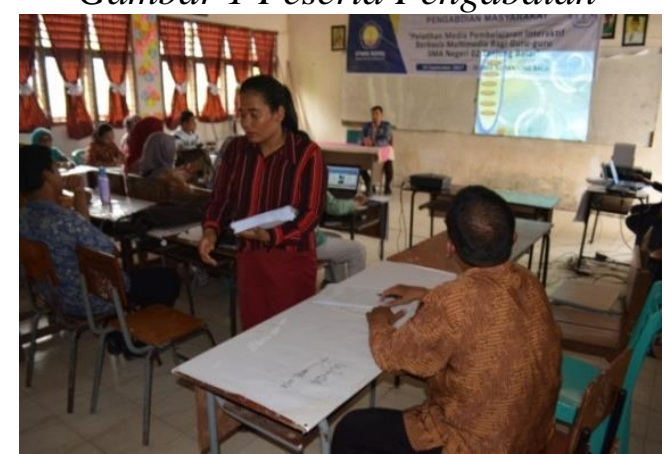

Gambar 2. Awal Pelatihan Peserta

\section{PEMBAHASAN}

Kegiatan pengabdian masyarakat yang telah direncanakan oleh dosen STMIK Royal Kisaran pada SMAN2 Tanjungbalai dengan tema Multimedia telah direalisasikan tanggal 16 September 2017. Jumlah peserta pelatihan 19 orang guru SMAN 2 Tanjungbalai.Kegiatan pengabdian masyarakat dilaksanakan di ruang kelas SMAN 2 Tanjungbalai.Untuk kelancaran pelatihan, pihak sekolah meminta masing-masing peserta membawa notebook/laptop.

Bentuk pelatihan yang diberikan meliputi materi kajian dasar dan materi kajian yang dijabarkan dalam langkahlangkah kerja. Pembahasan materi tersebut sesuai dengan materi yang telah dipersiapkan.Pembahasan menyangkut pengertian sampai ke manfaat aplikasi multimedi pembelajaran. Kemudian pembahasan dilanjutkan dengan pelatihan - pelatihan penggunaan dasar power point. Dari hasil observasi tim peneliti di lapangan, peserta cukup antusias dengan adanya pelatihan hal ini ditandai dengan rata-rata peserta membawa notebook mereka masingmasing untuk mencobakan setiap arahan yang diberikan instruktur dalam pelatihan. Selain itu, ternyata ada beberapa guru yang sudah cukup mahir menggunakan power point sebagai alat presentasi di kelas.

Namun saat menggunakan Aplikasi iSpring Question ini, masih banyak yang belum mengenal aplikasi tersebut untuk menunjang evaluasi pembelajaran. Ternyata hal tersebut memudahkan pendidik dalam membuat sebuah konten interaktif dalam menunjang proses pembelajaran. Kemudian aplikasi tersebut bisa diintegrasikan ke dalam power point melalui menu iSpring yang terintegrasi ke dalam power point.

Pembuatan bentuk interaktif yang ditampilkan tidak hanya kuis namun lebih banyak ke pola interaktif dalam bentuk menu. Dalam pembuatan menu, cukup memakan waktu untuk pelatihannya. Karena setiap peserta harus menggambar melalui power point. Untuk pengeditan gambar diselingi menggunakan editor gambar standar windows untuk mempercepat pelatihan. Kemudian untuk konversi ke vidio digunakan contain konversi yang disediakan oleh menu iSpring yang embeded dalam power point. Hanya saja ada beberapa system komputer 
peserta yang tidak mampu melakukan hal tersebut dikarenakan kemampuan sistem yang tidak sesuai dalam pengolahan multimedia.

Hasil dari kegiatan pengabdian masyarakat yang telah dilakukan oleh Tim dosen pengabdian masyarakat cukup sesuai dengan yang diharapakan dalam latarbelakan pengabdian.Peserta sudah mengerti dan memahami multimedia serta peranan multimedia dalam media pembelajaran.Peserta sudah memahami cara menerapkan aplikasi multimedia dalam pembelajaran. Selain itu peserta memahami keuntungan menggunakan aplikasi multimedia, pengaruh penggunaannya dalam pembelajaran serta pengaruh media pembelajaran bebasis multimedia terhadap kinerja guru.Peserta memahami dan mampu membuat setiap langkah pengerjaan 2. Media Pembelajaran Interaktif Berbasis Multimedia Bagi GuruGuru

SMAN 02 Tanjungbalai”. Selain melaksanakan tugas dari salah satu Tri Dharma perguruan tinggi yaitu pengabdian masyarakat, kegiatan ini juga merupakan bentuk sharing ilmu kepada para guru tentang pembuatan media pembelajaran berbasis multimedia. Kemudian kegiatan ini juga bertujuan untuk menjalin hubungan baik antara STMIK Royal Kisaran dengan SMAN 2 Tanjungbalai.

3. Manfaat yang dapat diperoleh dari kegiatan pengabdian mansyarakat ini adalah dosen mendapatkan tambahan angka kredit yang bisa digunakan dalam penilaian Beban Kerja Dosen. (BKD). Kemudian, dengan adanya pengabdian membantu dosen untuk mempertahankan pengetahuan yang dimiliki oleh dosen tersebut. Selain media pembelajaran berbasis multimedia menggunakan Micrososft Office Power Point 2010.Peserta cukup mengerti dan antusian menggunakan software add in, yang bisa disertakan untuk membantu menggerakan konteks multimedia di dalam Microsoft Office Power Point 2010 di atas, seperti iSpring Suit 8.

\section{SIMPULAN}

Adapun kegiatan pengabdian masyarakat ini dapat disimpulkan sebagai berikut:

1. Tema kegiatan pengabdian masyarakat yang dilakukan oleh Tim dosen STMIK Royal Kisaran pada SMA N 2 Tanjung Balai adalah "Pelatihan

itu, melalui pelatihan yang intensif, guru-guru SMA N 2 Tanjungbalai memiliki sudah memiliki pengetahuan mengenai cara yang user friendly dalam membuat media pembelajaran interaktif berbasis multimedia.

4. Bentuk kegiatan pengabdian masyarakat yang dilakukan adalah memberikan pelajaran dan pelatihan tentang tips dan trik serta pelatihan medesain aplikasi pembelajaran interaktif dan mengkonversikannya ke dalam video.

\section{DAFTAR PUSTAKA}

.Hamadin, dkk.2015. Pengembangan Media Pembelajaran Interaktif Berbasis Tik Dengan Pendekatan Saintifik.(Online).Diperoleh dari jurnal.fkip.unila.ac.id tanggal 10 
September 2017.

Budiman, Permana.2014. Microsoft Office Power Point.Yogyakarta: Elex Media Kompotindo.

Sunardi. 2017. Pemanfaatan Microsoft Powerpoint sebagai Media Pembelajaran. (Online).Diperoleh dari lp3m.unimus.ac.id tanggal 12

Waryanto, Nur Hadi. 2010. Membuat Desain Template Media Pembelajaran Interaktif.(Online).Diperoleh dari Staff.uny.ac.id tanggal 12 september 2017

Khotimah. 2008. Media Pembelajaran. Yogyakarta: CV Andi Offset.
Darudiato, Suprato. 2006. Analisis dan Perancangan Aplikasi Perangkat Ajar Berbasis Media. (Online). Diperoleh dari http://ejournal.uinsuska.ac.id/index.php/sitekin/articl e/view/599 tanggal 8 September 2017

Sutirman. 2011. Pengembangan Multimedia Interaktif untuk Meningkatkan Kualitas Pembelajaran Kewirausahaan di SMK Kelompok Bisnis dan Manajemen. (Online). Diperoleh dai staff.uny.ac.id tanggal 12 September 2017 